\title{
Predictive values of waist-to-height ratio for metabolic syndrome
}

\author{
${ }^{1}$ Biljana Srdić Galić, ${ }^{2}$ Edita Stokić, \\ ${ }^{2}$ Dragana Tomić-Naglić, ${ }^{1}$ Mirjana \\ Udicki, ${ }^{3}$ Aleksandar Kupusinac, ${ }^{3}$ Rade \\ Doroslovački, ${ }^{3}$ Dušan Malbaški \\ 'Department of Anatomy, Faculty of \\ Medicine, Hajduk Veljkova 3, Novi Sad, Serbia \\ ${ }^{2}$ Department of Endocrinology, Diabetes \\ and Metabolic Disorders, Institute of Internal \\ Disease, Clinical Centre of Vojvodina, Hajduk \\ Veljkova 1, Novi Sad, Serbia \\ ${ }^{3}$ Faculty of Technical Sciences, Trg Dositeja \\ Obradovića 6, Novi Sad, Serbia \\ Corresponding author: \\ Biljana Srdić Galić, MD, PhD \\ Department of Anatomy \\ Faculty of Medicine \\ 21000 Novi Sad, Serbia \\ Phone/fax: +381216615 751, \\ +381216615775 \\ E-mail address: biljana.srdic@uns.ac.rs; \\ biljana.srdic-galic@mf.uns.ac.rs
}

\begin{abstract}
Waist-to-height ratio (WHtR) has been shown to be a valuable predictor of cardiometabolic risk. Most studies recommend value of 0.5 as the predictive value for both genders and for all age groups. Considering body height changes with aging and gender-dependent differences in patterns of fat distribution with aging, the main purpose of this study was to assess age- and gender-specific predictive values of WHtR for metabolic syndrome. A total of 1517 subjects ( 725 men and 792 women) aged 18 to $67 y$ (BMI: $16.60-64.60 \mathrm{~kg} / \mathrm{m}^{2}$ ) were included in the study. According to IDF criteria for metabolic syndrome predictive values of WHtR were calculated for each age-category and both genders. WHtR showed higher predictive values in men than in women. In men, predictive values increase with aging from $0.52(<30 y)$ to $0.57(\geq 60 y)$, while in women they remain the same with aging (0.53). The accuracy of prediction was higher in older subjects. Comparing to WC, WHtR showed higher accuracy in determination of risky metabolic profile, while WC was better in identification of healthy metabolic profile. Our results revealed gender-specific predictive values of WhtR. In men, they show age-dependent dynamics. WHtR showed better performance than WC in the prediction of metabolic syndrome.
\end{abstract}

Key words: Obesity; Metabolic syndrome; Waist-to-height ratio; Waist circumference.

\section{INTRODUCTION}

It is very well known that abdominal obesity is strongly associated with major health consequencies of obesity, i.e. cardiovascular diseases and type 2 diabetes. Visceral fat depot is the major source of free fatty-acids and adipokines with proinflammatory and prothrombotic properties; it plays a central role in the development and progression of insulin resistance and cardiometabolic complications of obesity $[1,2]$.

Waist circumference alone is a widely used, simple and effective marker of abdominal visceral fat and health risks associated with obesity [3-5]; recommended cut-off points for waist circumference that correspond with higher cardiovascular risk $(\geq 80 \mathrm{~cm}$ for women and $\geq 94$ for men) are widely accepted in clinical practice. However, it has been shown that individuals with similar waist circumferences and different heights can differ in their health risks [6]. Three research groups suggested waist-to-height ratio ( $\mathrm{WHtR}$ ) as the better marker of the risk [7-9]. The value of 0.5 was suggested as the cut-off value that should indicate increased risk, while the value of 0.6 was taken as the upper value that indicates substantially increased risk $[7,10]$.
However, it has been acknowledged that the process of aging is characterized by decreasing body height and increasing fat mass with redistribution of fat tissue by means of visceral fat deposition, even if body weight and BMI are maintained $[11,12]$ which implies that WHtR cut-offs should differ with aging. Additionaly, several studes pointed to important role of the body height in cardiovascular risk $[13,14]$.

Considering different patterns of body fat distribution in men and women, age-dependent dynamics of fat distribution and body height changes, the objective of our study was to assess age- and gender-specific predictive values of WHtR for metabolic syndrome, as well as to compare prediction accuracy between WHtR and waist circumference.

\section{MATERIAL AND METHODS}

Study group consisted of 1517 subjects (725 men and 792 women) aged 18 to 67 years (average age was 43.44 \pm 10.80 ), with $B M I$ values between 16.60 and 64.60 $\mathrm{kg} / \mathrm{m}^{2}: 29,33 \%$ has normal-weight (BMI: $18.5-24.9 \mathrm{~kg} /$ $\mathrm{m}^{2}$ ), 30,19\% has overweight (BMI: $25-29,9 \mathrm{~kg} / \mathrm{m}^{2}$ ) and $40,47 \%$ was obese $\left(\mathrm{BMl} \geq 30 \mathrm{~kg} / \mathrm{m}^{2}\right)$. This investigation 
was taken as a part of a larger cross-sectional population study of the prevalence of obesity and cardiovascular risk factors among adult population living in the urban and rural areas of Vojvodina province situated in the northern part of Serbia. Participants were invited to participate in the study via local media, pamphlets and social networks. Participants underwent thorough medical evaluation; all the tests included were free of charge for all participants. The study was conducted in accordance with the Declaration of Helsinki. Average values of anthropometric parameters, blood pressure and metabolic parameters are given in the Table $\mathbf{1}$.

Table 1. Characteristics of the study sample.

\begin{tabular}{lll}
\hline & X \pm SD & Min-Max \\
\hline Age (years) & $43.44 \pm 10.80$ & $18.00-76.00$ \\
Body mass $(\mathrm{kg})$ & $86.05 \pm 19.99$ & $44.20-193.40$ \\
Body height $(\mathrm{cm})$ & $170.54 \pm 8.93$ & $139.40-198.00$ \\
BMI $\left(\mathrm{kg} / \mathrm{m}^{2}\right)$ & $29.65 \pm 6.95$ & $16.60-64.60$ \\
WC $(\mathrm{cm})$ & $95.85 \pm 16.40$ & $59.50-172.00$ \\
WHtR & $0.563 \pm 0.098$ & $0.356-1.012$ \\
FAT\% & $33.83 \pm 10.56$ & $5.80-60.80$ \\
SBP $(\mathrm{mmHg})$ & $130.99 \pm 18.46$ & $90.00-200.00$ \\
DBP $(\mathrm{mmHg})$ & $84.80 \pm 12.56$ & $50.00-130.00$ \\
Total cholesterol (mmol/l) & $5.91 \pm 1.34$ & $2.76-12.60$ \\
Triglycerides (mmol/l) & $1.93 \pm 1.64$ & $0.37-12.53$ \\
LDL-cholesterol (mmol/l) & $3.77 \pm 0.97$ & $1.79-9.65$ \\
HDL-cholesterol (mmol/l) & $1.17 \pm 0.29$ & $0.46-2.43$ \\
Total-/HDL-cholesterol & $5.36 \pm 1.85$ & $1.78-19.64$ \\
LDL-/HDL-cholesterol & $3.41 \pm 1.25$ & $0.82-12.87$ \\
Glycaemia (mmol/l) & $5.10 \pm 1.23$ & $3.00-13.10$ \\
\hline
\end{tabular}

Body height $(\mathrm{BH})$ was measured using Harpenden anthropometer with the precision of $0.1 \mathrm{~cm}$ and body mass (BM) was measured using balanced beam scale with the precision of $0.1 \mathrm{~kg}$. Waist circumference (WC) was measured using flexible tape with precision $0.1 \mathrm{~cm}$, at the level of middle distance between the lowest point on the costal arch and the highest point on the iliac crest.

In the assessment of metabolic risk we used IDF (The International Diabetes Federation) criteria for metabol- ic syndrome [15]- central obesity defined as WC $\geq 94$ $\mathrm{cm}$ for men (GENDER=0) and $W C \geq 80 \mathrm{~cm}$ for women (GENDER=1) plus any two of the following factors: triglycerides $\geq 1.7 \mathrm{~mol} / \mathrm{l}, \mathrm{HDL}$-cholesterol $<1.03 \mathrm{mmol} / \mathrm{l}$ for men and $<1.29 \mathrm{mmol} / \mathrm{l}$ for women, systolic blood pressure $\geq 130 \mathrm{mmHg}$, diastolic blood pressure $\geq 85 \mathrm{mmHg}$ and glycaemia $\geq 5.6 \mathrm{mmol} / \mathrm{l}$.

Blood pressure was measured early in the morning after 5 minutes resting, using sphingomanometer Riva-Rocci. Total cholesterol and total triglyceride levels were determined by an enzyme-based method, HDL-cholesterol levels were determined by the precipitation method with sodium phospho-wolframate, and LDL-cholesterol levels were calculated using the Friedwald et al. formula. Fasting glucose levels were determined by Dialab glucose GOD-PAP method, and serum insulin levels were determined by ELISA.

\section{Determining predictive values of WHtR}

At first, the total number of metabolic risk factors ( $m s$ coefficient) was calculated for every responder. Average values of WC and WHtR were directly proportional to the number of metabolic risk factors (Table 2). Next, the risky and risk-free zones were defined, using the values of WC and ms coefficient: a responder belongs to the risky zone if $W C \geq 94 \mathrm{~cm}$ for men and $W C \geq 80 \mathrm{~cm}$ for women and if $m s \geq 2$; a responder belongs to the risk-free zone if $W C<94 \mathrm{~cm}$ for men and $W C<80 \mathrm{~cm}$ for women and if $m s<2$ [15].

The respondents with hazardously enlarged waist circumference were extracted (men $\geq 94 \mathrm{~cm}$; women $\geq 80 \mathrm{~cm}$ ) and distributed into 5 age groups: <30, 30$39,40-49,50-59, \geq 60 y$, and every group was sorted according the $m s$ coefficient. The values of WHtR were observed as a function of the ms coefficient. As expected, the function was highly nonlinear so the linear regression was performed. For every age group the critical value of WHtR was calculated for $m s=2$ and the linear regression was performed producing values that correspond to the lower limit for the risky zone. The same procedure was applied to the respondents with normal values of WC (men $<94 \mathrm{~cm}$; women $<80 \mathrm{~cm}$ ), and by linear regression the upper limits were defined for the risk-free zone.

Table 2. Average values of WC and WHtR in the groups of different metabolic risks.

\begin{tabular}{llllllll}
\hline Group & Total & $m s=0$ & $m s=1$ & $m s=2$ & $m s=3$ & $m s=4$ & $m s=5$ \\
\hline Men & & & & & & & \\
Number & 725 & 66 & 162 & 126 & 215 & 114 & 42 \\
WC (cm) & 98.429 & 92.0682 & 95.3981 & 97.7968 & 99.1265 & 103.6140 & 104.3667 \\
WHtR & 0.5585 & 0.5178 & 0.5395 & 0.5530 & 0.5628 & 0.5924 & 0.5976 \\
Women & & & & & & & \\
Number & 792 & 133 & 162 & 173 & 167 & 117 & 40 \\
WC (cm) & 93.4807 & 80.9504 & 88.6012 & 95.9353 & 97.9551 & 101.4137 & 102.4050 \\
WHtR & 0.5672 & 0.4916 & 0.5372 & 0.5788 & 0.5956 & 0.6164 & 0.6279 \\
\hline
\end{tabular}


For every age group the predictive value was calculated as an average between the lower limit of risky zone and the upper limit of risk-free zone (dashed line on the Figures 1 and 2).

\section{Comparison of WC and WHtR in the prediction of the metabolic syndrome}

In order to compare WC and WHtR in metabolic risk prediction, a MATLAB (Version 7.0) program was implemented to test the following 8 assertions on our dataset:

1. If a person is male and if $W C \geq 94 \mathrm{~cm}$ then $m s \geq 2$.

2. If a person is male and if $W C<94 \mathrm{~cm}$ then $m s<2$.

3. If a person is female and if $W C \geq 80 \mathrm{~cm}$ then $m s \geq 2$.

4. If a person is female and if $W C<80 \mathrm{~cm}$ then $m s<2$.

5. If a person is male and belongs to the age group AGE and if $W H t R \geq W H t R^{*}(A G E)$ then $m s \geq 2$.

6. If a person is male and belongs to the age group $A G E$ and if $\mathrm{WHtR}<\mathrm{WHtR}$ (AGE) then $m s<2$.

7. If a person is female and belongs to the age group $A G E$ and if $W H t R \geq W H t R^{*}(A G E)$ then $m s \geq 2$.

8. If a person is female and belongs to the age group $A G E$ and if $W H t R<W H t R^{*}(A G E)$ then $m s<2$.

\section{RESULTS}

According to the values from the Table $\mathbf{3}$ we can notice that lower limits of WHtR for the risky zone are higher in women (in average 0.5930 for men and 0.6089 for women). Upper limits of the risk-free zone are higher in men in all age groups. In men, lower limits of risky zone are growing with aging, while in women they are falling down. Upper limits of the risk-free zone grow with aging in both genders but the increasement is faster in men (Figures $\mathbf{1}$ and 2).

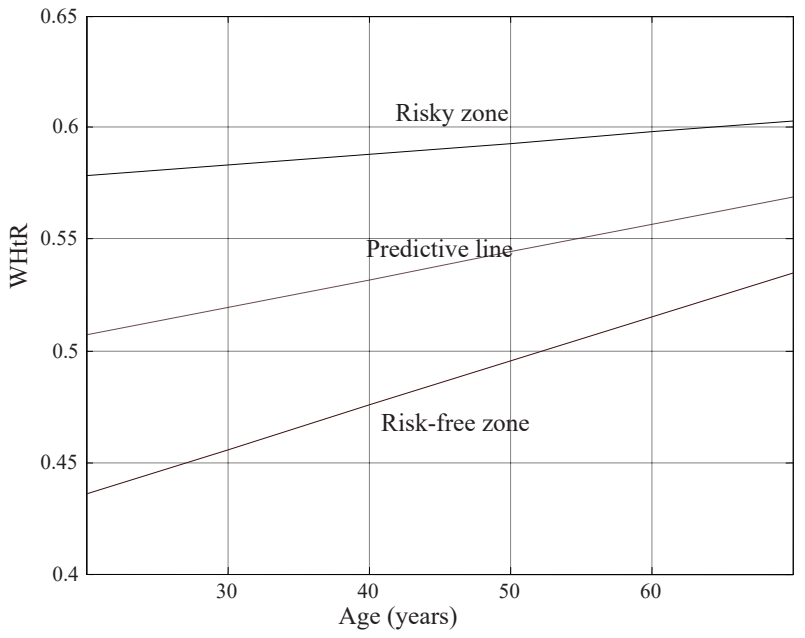

Figure 1. Metabolic risk prediction based on WHtR values in men

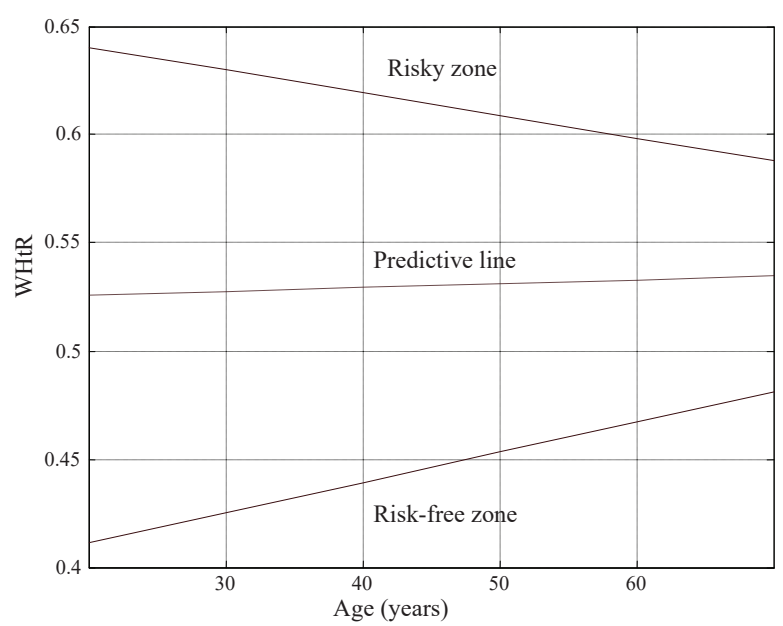

Figure 2. Metabolic risk prediction based on WHtR values in women

Table 3. Limits for WHtR obtained by linear regression.

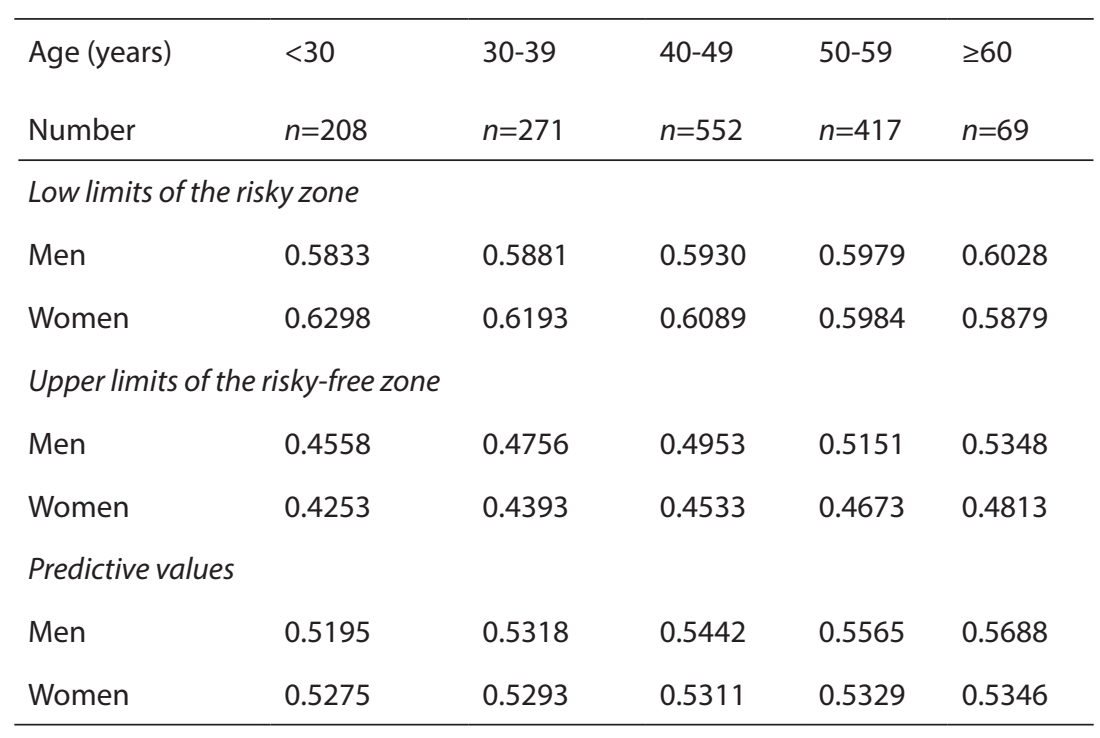

The Tables 4 and $\mathbf{5}$ contain comparative data on the accuracy of the metabolic risk prediction by WC and WHtR. The data obtained show that the parameter WHtR is better than WC when detecting the risky profile and worse for detection of the healthy profile. The accuracy of risky metabolic profile detection using WHtR $\left(\mathrm{AC}_{\mathrm{WHtR}}\right)$ is $76.45 \%$, while the prediction accuracy for $\mathrm{WC}\left(\mathrm{AC}_{\mathrm{WC}}\right)$ is $74.17 \%$, meaning that $\mathrm{WHtR}$ is $2.28 \%$ better than WC in average. The accuracy of the healthy profile prediction based on WHtR is $48.21 \%$, whereas the value based on WC is $52.55 \%$, i.e. WHtR is in average $4.34 \%$ worse than WC. The accuracy if the risky profile prediction based on $\mathrm{WHtR}$ is $76.47 \%$ for men and $76.43 \%$ for women. The 
maximal accuracy of risky metabolic profile prediction using WHtR is calculated for the age group 50-59y for men (84.42\%) and 40-49y for women (85.29\%). The accuracy of healthy profile prediction based on WHtR is $40.72 \%$ for men and $55.62 \%$ for women. The maximal accuracy is determined for the age group 30-39y for men (60.87\%) and $\geq 60 y$ for women (76.92\%).

Table 4. Prediction accuracy (AC) of WC and WHtR in the detection of risky metabolic profile.

\begin{tabular}{|c|c|c|c|}
\hline Age (years) & $\mathrm{AC}_{\mathrm{wc}}(\%)$ & $\mathrm{AC}_{\mathrm{WHtR}}(\%)$ & $A C_{w H t R}-A C_{w c}$ \\
\hline \multicolumn{4}{|l|}{ Men } \\
\hline & 75.22 & 76.47 & 1.25 \\
\hline$<30$ & 56.00 & 57.89 & 1.89 \\
\hline $30-39$ & 72.22 & 76.47 & 4.25 \\
\hline $40-49$ & 70.91 & 71.03 & 0.12 \\
\hline $50-59$ & 82.95 & 84.42 & 1.47 \\
\hline$\geq 60$ & 75.00 & 72.73 & -2.27 \\
\hline \multicolumn{4}{|l|}{ Women } \\
\hline & 73.34 & 76.43 & 3.09 \\
\hline$<30$ & 64.81 & 67.74 & 2.93 \\
\hline $30-39$ & 66.36 & 69.15 & 2.79 \\
\hline $40-49$ & 79.89 & 85.29 & 5.40 \\
\hline $50-59$ & 78.77 & 81.58 & 2.81 \\
\hline$\geq 60$ & 57.14 & 58.82 & 1.68 \\
\hline \multicolumn{4}{|l|}{ Total } \\
\hline & 74.17 & 76.45 & 2.28 \\
\hline
\end{tabular}

Table 5. Prediction accuracy (AC) of WC and WHtR in the detection of healthy metabolic profile.

\begin{tabular}{|c|c|c|c|}
\hline Age (years) & $A C_{w c}(\%)$ & $A C_{W H t R}(\%)$ & $A C_{W H t R}-A C_{w c}$ \\
\hline \multicolumn{4}{|l|}{ Men } \\
\hline & 42.49 & 40.72 & -1.77 \\
\hline$<30$ & 46.15 & 46.67 & 0.52 \\
\hline $30-39$ & 58.14 & 60.87 & 2.73 \\
\hline $40-49$ & 42.61 & 40.74 & -1.87 \\
\hline $50-59$ & 31.88 & 30.77 & -1.11 \\
\hline$\geq 60$ & 28.57 & 23.53 & -5.04 \\
\hline \multicolumn{4}{|l|}{ Women } \\
\hline & 65.14 & 55.62 & -9.52 \\
\hline$<30$ & 75.00 & 68.63 & -6.37 \\
\hline $30-39$ & 67.19 & 63.75 & -3.44 \\
\hline $40-49$ & 55.42 & 47.06 & -8.36 \\
\hline $50-59$ & 69.23 & 48.28 & -20.95 \\
\hline$\geq 60$ & 88.89 & 76.92 & -11.97 \\
\hline \multicolumn{4}{|l|}{ Total } \\
\hline & 52.55 & 48.21 & -4.34 \\
\hline
\end{tabular}

\section{DISCUSSION}

This study was conducted with an aim to determine age and gender-dependent predictive values of WHtR for metabolic syndrome. Our results confirmed that, apart from waist circumference, body height measurement increases accuracy of metabolic risk prediction. Predictive values of WHtR differ between men and women and show age-dependent dynamics in men.

Recognized importance of abdominal fat deposition has led to an increased interest in establishing standards for diagnosis of abdominal obesity. Waist circumference is suggested as a good indicator of both, visceral fat mass and cardiovascular risk [8,16-18]. Nevertheless, some studies have proved that WHtR shows superiority over other anthropometric indicators of cardiometabolic risk [19,20]. Using waist circumference relative to body height is more appropriate for a few reasons. First of all, body circumferences correlate with body height reflecting biomechanical properties of underlying structures, particularly in men [21]. Thus, taller individuals would have a larger waist circumference which certainly doesn't mean that cardiometabolic risk increases with body height. On contrary, body height has been shown to have inverse relationship with cardiovascular morbidity [13,14,22]. Heymsfield et al. [21] also found lower values of WHtR in taller persons which they explain by the fact that waist circumference increases at the slower rate than does body height. Take for example, two men aged $43 y$ with the same waist circumferences $(95 \mathrm{~cm})$ - first one is $187 \mathrm{~cm}$ tall, while the other is $162 \mathrm{~cm}$ tall; they differ in they WHtRs: 0.5080 and 0.5864 , respectively. According to our results, in the first case WHtR closes to the healthy zone (in average 0.4953 for age-category $40-49 y$ ) while the second men from the example is at higher metabolic risk, with high accuracy (71.03\%). At the same time, using of WHtR could prevent potential misclassifications done by using of WC alone - an 65 year old woman with WC $82 \mathrm{~cm}$, which is considered as increased value, and body height $168 \mathrm{~cm}(\mathrm{WHtR}=0.488)$ can be considered without risk. According to the results of the large meta-analysis including data from several ethnic groups taken by Ashwell et al., [23] WHtR gave the best discrimination over WC for cardiovascular outcomes, diabetes, dyslipidemia and combined outcomes. Our results also show higher accuracy of WHtR comparing to WC in the determination of risky metabolic profile, particularly in middle-aged individuals of both genders.

Most studies found predictive value of WHtR 0.5 $[5,7,24,25]$. Rodriques et al. [26] defined WHtR cut-off values for metabolic syndrome: 0.53 for men, and 0.54 for women. Lin et al. [20] established even lower cutoffs for Taiwanese population: 0.48 for men and 0.45 for women. Our cut-offs were higher in men in all agegroups except in the youngest one (men: 0.52, women: 0.53). Predictive values of WHtR in women didn't change much with aging - in all age-groups they were 0.53 . However, the precision of prediction has been 
shown to be higher in older women. In men, cut-offs raised with aging from 0.52 to 0.57 , which means that the same values of waist circumference and body height in two men of different ages hold different metabolic risks. For example, two men aged 35y and 62y with the same WHtR 0.56 differ in their risks - younger one is at the higher risk than the older one. This could be in line with the phenomenon of "obesity paradox" in older individuals $[27,28]$.

There are also ethnic-related differences in visceral fat size and body height. Recommended values of WC could underestimate visceral fat size in populations like Chinese and South Asians [3]. Accordingly, cut-offs for WHtR will differ across populations. Considering additional variations of body heigh and probably different age- and gender-dependent risk across different populations, there is a need to define population-specific predictive values for WHtR.

This study brings new insight regarding to criteria used in the definition of the metabolic syndrome. In order to properly define metabolic risk waist circumference should be considered in relation with the longitudinal body dimension.

Considering constraints of this study, there is a need to mention a relatively small sample and inclusion of metabolic risk factors only. Establishing more accurate limits for WHtR needs the more comprehensive approach to cardiometabolic risks of obesity, including all patophysiological aspects of enlarged visceral fat. The interpretation of the results for the oldest group should be taken with caution because of the lowest number of subjects.

\section{CONCLUSION}

In the conclusion, according to the Serbian population-based study results predictive values of $\mathrm{WH} \mathrm{tR}$ are higher in men than in women; in men they increase with aging while in women they don't change after the age of 30. Additionally, predictive accuracy of WHtR increases with aging, which makes it more appropriate indicator in older persons than waist circumference.

\section{Statement of Authorship}

All authors have read and approved the final manuscript: BS participated in design of the study, collection and analysis of data and writing of manuscript, ES participated in design of the study, collection and analysis of data, and provided significant consultation, DTN and MM participated in collection and analysis of data, AK participated in the design of study, statistical analysis of data and writing of manuscript, RD and DM participated in statistical analysis of data and provided significant consultation.

\section{Conflict of Interest Statement}

All authors certify that there are none conflicts of interest.

\section{Funding sources}

This work was partially supported by the Ministry of Science and Education of the Republic of Serbia within the projects: ON 174026 and III 044006, and by the Provincial Secretariat for Science and Technological Development (number: 114-451-2337/2011-01).

\section{REFERENCES}

1. Bosello O, Zamboni M. Visceral obesity and metabolic syndrome. Obes Rev 2000;1:47-56.

2. Ritchie SA, Connell JMC. The link between abdominal obesity, metabolic syndrome and cardiovascular disease. Nutr Metab Cardiovasc Dis 2007;17(4):319-326.

3. Stevens J, Katz EG, Huxley RR. Associations between gender, age and waist circumference. Eur J Clin Nutr 2010;64:6-15.

4. Despres J, Moorjani, S, Lupien, PJ, Tremblay A, Nadeau A, Bouchard C. Regional distribution of body fat, plasma lipoproteins, and cardiovascular disease. Arteriosclerosis 1990;10(4):497-511.

5. Ashwell M. Waist to height ratio and the Ashwell1 shape chart could predict the health risks of obesity in adults and children in all ethnic groups. Nutr Food Sci 2005;35(5):359-64.

6. Hsieh S, Yoshinaga H. Do people with similar waist circumference share similar health risks irrespective of height? Tohoku J Exp Med 1990;188:55-60.

7. Hsieh SD, Yoshinaga H. Abdominal fat distribution and coronary heart disease risk factors in men - waist/ height ratio as a simple and useful predictor. Int J Obes 1995; 19:585-9.

8. Lee CM, Huxley RR, Wildman RP et al. Indices of abdominal obesity are better discriminators of cardiovascular risk factors than BMI: a meta-analysis. J Clin Epidemiol 2008;61 (7):646-53.

9. Ashwell MA, LeJeune SRE, McPherson K. Ratio of waist circumference to height may be better indicator of need for weight management. Brit Med J 1996;312:377.

10. Ashwell M. The Ashwell Shape Chart - a public health approach to the metabolic risks of obesity. Int J Obes 1998;22:S213.

11. Kuk JL, Lee S, Heymsfield SB, Ross R. Waist circumference and abdominal adipose tissue distribution: influence of age and sex. Am J Clin Nutr 2005;81:1330-4.

12. Cartwright MJ, Tchkonia T, Kirkland JL. Aging of adipocytes: potential impact of inherent, depot-specific mechanisms. Exp Gerontol 2007;42:463-71.

13. Forsen T, Eriksson J, Qiao Q, Tervahauta M, Nissinen A, Tuomilehto J. Short stature and coronary heart disease: a 35-year follow-up of the Finnish cohorts of the Seven Countries Study. J Intern Med 2000;248(4):326-32.

14. López-Alvarenga JC, Montesinos-Cabrera RA, VelázquezAlva C, González-Barranco J. Short stature is related to high body fat composition despite body mass index in a Mexican population. Arch Med Res 2003;34:137-40. 
15. The IDF consensus worldwide definition of the metabolic syndrome 2006. (http://www.idf.org/webdata/docs/ MetS_def_update2006.pdf). Accessed Oct. 2011.

16. Pouliot MC, Despres JP, Lemieux S, Moorjani S, Bouchard C, Tremblay A. Waist circumference and abdominal sagittal diameter: best simple anthropometric indexes of abdominal visceral adipose tissue accumulation and related cardiovascular risk in men and women. Am J Cardiol 1994:73(7):460-8.

17. de Koning L, Merchant AT, Pogue J, Anand SS. Waist circumference and waist-to-hip ratio as predictors of cardiovascular events: meta-regression analysis of prospective studies. Eur Heart J 2007;28(7):850-6.

18. Snijder MB, van Dam RM, Visser M, Seidell JC. What aspects of body fat are particularly hazardous and how do we measure them? Int J Epidemiol 2006;35:83-92.

19. Cox BD, Whichelow M. Ratio of waist circumference to height is better predictor of death than body mass index. BMJ 1996;313(7070):1487.

20. Lin WY, Lee LT, Chen CY, Lo H, Hsia HH, Liu IL, Lin RS, Shau WY, Huang KC. Optimal cut-off values for obesity: using simple anthropometric indices to predict cardiovascular risk factors in Taiwan. Int J Obes 2002;26:1232-8.

21. Heymsfield SB, Heo M, Pietrobelli A. Are adult body circumferences associated with height? Relevance to normative ranges and circumferential indexes. Am J Clin Nutr 2011;93:302-7.
22. Lara-Esqueda A, Aguilar-Salinas CA, Velazquez-Monroy O, Gómez-Pérez FJ, Rosas-Peralta M, Mehta R et al. Int J Obes Relat Metab Disord 2004;28(11):1443-50.

23. Ashwell M, Gunn P, Gibson S. Waist-to-height ratio is a better screening tool than waist circumference and BMI for adult cardiometabolic risk factors: systematic review and meta-analysis. Obes Rev 2012;13(3):275-86.

24. Bertsias G, Mammas I, Linardakis M, Kafatos A. Overweight and obesity in relation to cardiovascular disease risk factors among medical students in Crete, Greece. BMC Pub Health 2003;3(1):3.

25. Browning LM, Hsieh SD, Ashwell M. A systematic review of waist-to-height ratio as a screening tool for the prediction of cardiovascular disease and diabetes: 0.5 could be a suitable global boundary value. Nutr Res Rev 2010;23:247-69.

26. Rodrigues SL, Baldo MP, Mill JG. Association of waist-stature ratio with hypertension and metabolic syndrome: population-based study. Arq Bras Cardiol 2010;95(2):186-91.

27. Dorner TE, Rieder A. Obesity paradox in elderly patients with cardiovascular diseases. Int J Cardiol 2012;155:56-65.

28. Arena R, Lavie CJ. The obesity paradox and outcome in heart failure: is excess bodyweight truly protective? Future Cardiol 2010;6(1):1-6.

\section{Prediktivne vrednosti odnosa obima struka i telesne visine u metaboličkom sindromu}

\section{'Biljana Srdić Galić, ${ }^{2}$ Edita Stokić, ${ }^{2}$ Dragana Tomić-Naglić, ${ }^{1}$ Mirjana Udicki, ${ }^{3}$ Aleksandar Kupusinac, ${ }^{3}$ Rade Doroslovački, ${ }^{3}$ Dušan Malbaški}

${ }^{1}$ Katedra za Anatomiju, Medicinski fakultet, Hajduk Veljkova 3, Novi Sad, Srbija

${ }^{2}$ Odeljenje za endokrinologiju, dijabetes i bolesti metabolizma, Institut za interne bolesti, Klinički centar Vojvodine, Hajduk Veljkova 1, Novi Sad, Srbija

${ }^{3}$ Fakultet tehničkih nauka, Trg Dositeja Obradovića 6, Novi Sad, Serbia

\begin{abstract}
Kratak sadržaj
Poznato je da odnos obima struka i telesne visine (waist-to-height ratio, WHtR) predstavlja dobar pokazatelj kardiometaboličkog rizika. Većina studija preporučuje referentnu vrednost WHtR od 0,5 za oba pola i za sve starosne kategorije. Imajući u vidu starosno uslovljene promene telesne visine kao i polno specifične promene obrasca distribucije masnog tkiva tokom starenja, osnovni cilj ovog istraživanja bio je da se generišu starosno i polno specifične referentne vrednosti WHtR za predikciju metaboličkog sindroma. U studiju je uključeno 1517 osoba oba pola (725 muškaraca and 792 žene) starosti 18-67 godina (indeks telesne mase: $16,60-64,60 \mathrm{~kg} / \mathrm{m}^{2}$ ). Metabolički sindrom je dijagnostikovan primenom IDF kriterijuma. a potom su izračunate prediktivne vrednosti WHtR za oba pola i za sve starosne grupe. WHtR se pokazao boljim u predikciji metaboličkog sindroma kod muškaraca nego kod žena. Granična vrednost se kod muškaraca povećavala sa starenjem (od 0,52 za grupu starosti ispod 30 godina do 0,57 za grupu starosti 60 i više godina), dok se kod žena nije menjala tokom starenja $(0,53)$. Pouzdanost predviđanja metaboličkog sindroma bila je veća kod starijih osoba. U poređenju sa obimom struka WHtR se pokazao boljim u determinisanju rizičnog metaboličkog sindroma, dok se obim struka pokazao boljim u identifikaciji zdravog metaboličkog profila. Prediktivne vrednosti WHtR se razlikuju u odnosu na pol, a kod muškaraca pokazuju i zavisnost od starosti. U poređenju sa obimom struka WHtR se pokazao boljim u predikciji metaboličkog sindroma.
\end{abstract}

Ključne reči: Gojaznost; Obim struka; Odnos obima struka i telesne visine; Metabolički sindrom. 